Jurnal Akuntansi \& Perpajakan, Volume 2, No. 2, Januari 2021

\title{
PENGARUH PENGETAHUAN PENGGUNAAN FINTECH (OVO DAN GOPAY) TERHADAP LITERASI KEUANGAN
}

\author{
Oktavia Marpaung \\ Sekolah Tinggi Ilmu Ekonomi Jayakarta
}

\begin{abstract}
ABSTRAK
Tujuan dari penelitian ini adalah untuk mengetahui Pengaruh Pengetahuan Penggunaan Fintech (Ovo Dan Gopay) Terhadap Literasi Keuangan. Metode yang digunakan pada penelitian ini adalah metode kuantitatif jenis deskriptif, Dalam penelitian ini menggunakan teknik sampling Probability Sampling. Probability Sampling adalah teknik pengambilan sampel yang memberikan peluang yang sama bagi setiap unsur (anggota) populasi untuk dipilih menjadi sampel. Hasil penelitian dapat diketahui dengan melihat koefesien korelasi adalah 0,794. artinya nilai ini dapat menunjukkan hubungan yang sangat kuat antara Pengetahuan Penggunaan Fintech : Ovo / GoPay dengan Literasi Keuangan (Y), nilai koefesien korelasi semakin mendekati ke 1 maka semakin sempurna hubungan antara kedua variabel tersebut (arah hubungan ke positif). Dilihat pada tabel model summary dengan hasil tersebut dapat diketahui bahwa nilai $R$ sebesar 0,794 atau koefesien korelasi nilai $R$ tersebut dapat dikuadratkan yaitu 0,794 x 0,794=0,630. $\mathrm{R}$ square (koefesien determinasi) dalam hal ini variasi dari variabel terikat (Literasi Keuangan (Y)) dapat dijelaskan oleh variabel bebas (Pengetahuan Penggunaan Fintech : Ovo / GoPay (X)) yaitu sebesar 63,0\%. sedangkan sisanya $37,0 \%$ dipengaruhi oleh faktor yang lain. Kesimpulan dari penelitian ini adalah bahwa Pengetahuan penggunaan Fintech Ovo/Gopay berpengaruh sangat kuat dan positif terhadap Literasi Keuangan. Dan bisa dikatakan orang yang menggunakan fintech yaitu ovo/gopay akan memiliki pemahaman tentang literasi keuangan.
\end{abstract}

Kata-kata Kunci : Fintech, Literasi Keuangan, Kuantitatif

\section{ABSTRACT}

The purpose of this study was to determine the effect of the influence of knowledge on the use of fintech (Ovo and Gopay) on financial literacy. The method used in this research is descriptive quantitative type. In this study using the sampling technique Probability Sampling. Probability Sampling is a sampling technique that provides equal opportunities for each element (member) of the population to be selected as a sample. The result of this research can be seen by looking at the correlation coefficient of 0.794. meaning that this value can show a very strong relationship between Knowledge of Fintech Use: Ovo / GoPay and Financial Literacy (Y), the correlation coefficient value is closer to 1, the more perfect the relationship between the two variables (the direction of the relationship is positive). Seen in the model summary table with these results it can be seen that the $R$ value of 0.794 or the correlation coefficient of the $R$ value can be squared, namely $0.794 \times 0.794=0.630 . R$ square (coefficient of determination) in this case the variation of the dependent variable (Financial Literacy $(Y)$ ) can be explained by the independent variable (Knowledge of Fintech Usage: Ovo / GoPay (X)) which is $63.0 \%$. while the remaining $37.0 \%$ is influenced by other factors. The conclusion of this study is that Knowledge of the use of Fintech Ovo / Gopay has a very strong and positive effect on Financial Literacy. And it can be said that people who use fintech, namely ovo / gopay, will have an understanding of financial literacy.

Keywords : Fintech, Financial Literacy, Quantitative

Korespondensi: Oktavia Marpaung, S.E., M.Ak. Sekolah Tinggi Ilmu Ekonomi Jayakarta. J1. Salemba Raya no. 24, Jakarta Pusat, 10430. Email: Oktavia.jykt@gmail.com 
Jurnal Akuntansi \& Perpajakan, Volume 2, No. 2, Januari 2021

\section{PENDAHULUAN}

Perkembangan teknologi Sekarang ini tidak pernah lepas dari kehidupan manusia yang memiliki banyak aktifitas. Perkembangan teknologi informasi dan komunikasi telah menyebabkan perubahan baik dibidang sosial, ekonomi dan budaya yang berlangsung begitu cepat. Dengan perkembangan teknologi yang sangat maju, dibidang finansial juga memiliki perkembangan ke arah yang lebih efisien dan modern. Dalam bidang perekonomian dunia saat ini sangat penting untuk memberikan inovasi teknologi didalamnya. Teknologi dan finansial memiliki hubungan yang berkaitan. Saat ini telah hadir teknologi yang mengarah pada inovasi finansial dengan sentuhan teknologi modern bernama Financial Technology.

Hasil penelitian (Wiyono \& Kirana, 2020) menunjukkan bahwa manfaat fintech berpengaruh positip dan signifikan terhadap perilaku keuangan UKM untuk berniat menggunakannya. Semakin manfaatnya bertambah, perilaku penggunaan fintech semakin berkembang.

Menurut penelitian yang dilakukan oleh (Mertha Dewi \& Purbawangsa, 2018) bahwa hal ini menjelaskan bahwa pemahaman yang baik mengenai keuangan menjadi faktor utama dalam menentukan keputusan sebuah investasi dan penggunaan keuangan pribadi.

\section{Tabel.1}

\section{Nilai Transaksi Fintech}

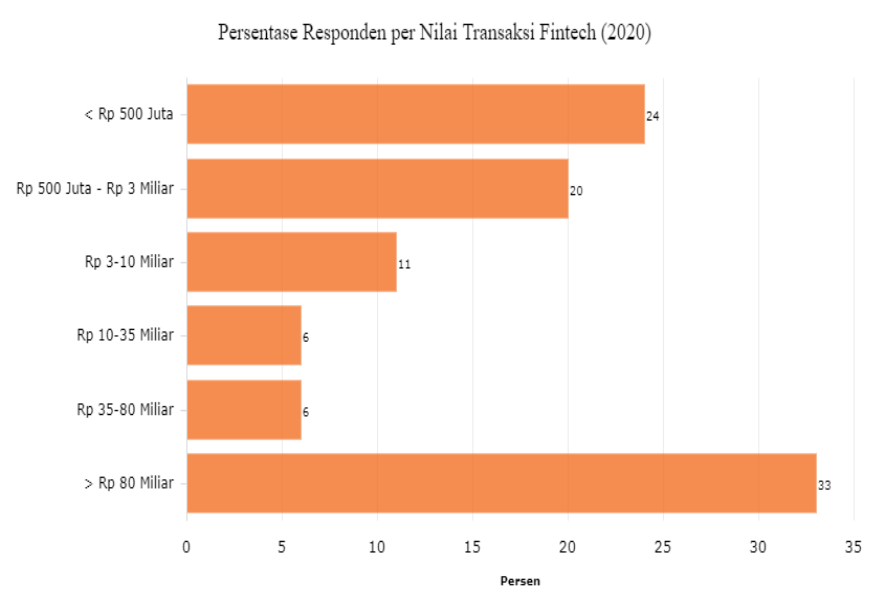

Sumber : databoks.katadata. 2020

Asosiasi Fintech Indonesia (AFTECH) merilis hasil survei nilai transaksi yang dilakukan perusahaan teknologi finansial (fintech) di Indonesia. Sebanyak 33\% responden memiliki nilai transaksi lebih dari Rp 80 miliar, sedangkan 24\% lainnya hanya melakukan transksi kurang dari Rp 500 juta. Kemudian, sebanyak 20\% mencatatkan nilai transaksi sebesar Rp 500 juta sampai Rp 3 miliar dan 11\% yang melakukan transaksi senilai Rp 3-10 miliar. Hanya 6\% responden yang bertransaksi Rp 10-35 miliar dan Rp 35-80 miliar.

Tabel.2

Literasi Keuangan di daerah Indonesia

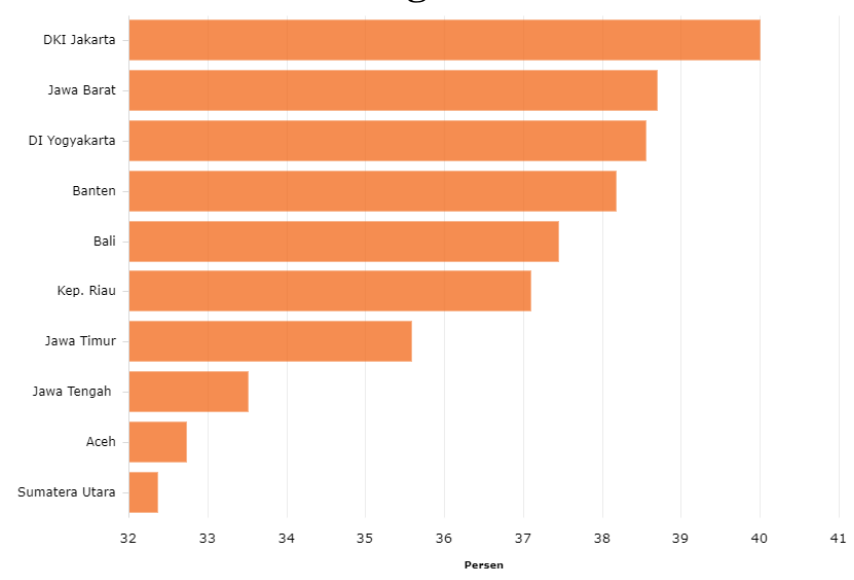

Sumber : databoks.katadata. 2020 
Jurnal Akuntansi \& Perpajakan, Volume 2, No. 2, Januari 2021

Otoritas Jasa Keuangan (OJK) kembali mempublikasikan Survei Nasional Literasi dan Inklusi Keuangan (SNLIK) pada 2016. Indeks literasi keuangan tertinggi masih didominasi provinsi di kawasan-kawasan Jawa dan Bali. Skor indeks tertinggi terjadi di DKI Jakarta mencapai 40 persen. Diikuti Jawa Barat dan DI Yogyakarta dengan 38,70 persen dan 38,55 persen. Sementara secara nasional, indeks literasi keuangan Indonesia pada 2016 mencapai 29,66 persen. Angka tersebut meningkat dibanding survei serupa pada 2013 yang tercatat sebesar 21,84. Indeks literasi keuangan SBLIK pada 2016 mencakup 9.860 responden di 34 provinsi yang tersebar di 64 kota/kabupaten di Indonesia dengan mempertimbangkan gender, strata wilayah, umur, pengeluaran, pekerjaan, dan tingkat pendidikan.

Seperti yang diketahui pengertian literasi keuangan menurut Otoritas Jasa Keuangan, literasi keuangan merupakan pengetahuan, keterampilan, dan keyakinan yang mempengaruhi sikap dan perilaku untuk meningkatkan kualitas pengambilan keputusan dan pengelolaan keuangan dalam rangka mencapai kesejahteraan. Dari pengertian tersebut dapat dijelaskan bahwa literasi keuangan akan berbanding lurus dengan pengambilan keputuan dan pengelolaan keuangan atau apabila semakin bagus literasi keuangan yang dimiliki maka akan semakin tepat seseorang dalam mengambil keputusan keuangan dan semakin baik dalam mengelola keuangan.
Tujuan dari penelitian ini Adalah untuk mengetahui pengaruh Pengaruh Pengetahuan Penggunaan Fintech (Ovo Dan Gopay) Terhadap Literasi Keuangan.

\section{TINJAUAN LITERATUR}

Fintech berasal dari istilah financial technology atau teknologi finansial. Menurut The National Digital Research Centre (NDRC), di Dublin, Irlandia, mendefinisikan fintech sebagai "innovation infinancial services" atau "inovasi dalam layanan keuangan fintech" yang merupakan suatu inovasi pada sektor finansial yang mendapat sentuhan teknologi modern. Transaksi keuangan melalui fintech ini meliputi pembayaran, investasi, peminjaman uang, transfer, rencana keuangan dan pembanding produk keuangan. (Muhamad Rizal, Erna Maulina, 2018).

Aplikasi OVO adalah aplikasi pembayaran elektronik yang baru resmi diluncurkan pada Maret 2017. Aplikasi OVO merupakan salah satu platform yang digunakan sebagai media transaksi dalam melakukan pembayaran dengan metode pembayaran elektronik atau secara digital yang didalamnya terdapat saldo OVO Cash, dimana pengguna dapat mengoperasikan sepenuhnya aplikasi tersebut melalui mobile phone. (Safitri \& Andriansyah, 2020).

GOJEK menjadi media penghubung bagi pengemudi dan penumpang. GOJEK berkomitmen untuk menyejahterakan mitra 
Jurnal Akuntansi \& Perpajakan, Volume 2, No. 2, Januari 2021

kerjanya, pengemudi tanpa terkecuali. Komitmen GOJEK diawali dengan memberitahu kepada semua orang bahwa mereka adalah startup asli Indonesia dengan misi sosial. Mereka ingin meningkatkan kesejahteraan sosial dengan menciptakan efisiensi pasar. Melalui teknologi mereka berusaha menyebarkan dampak sosial yaitu kehidupan yang lebih baik untuk driver dan keluarganya dengan meningkatkan jumlah penghasilan mereka. Layanan utama GOJEK sangat penting bagi kota dengan tingkat lalu lintas yang padat seperti Jakarta dan kota lainnya di mana mereka beroperasi. GOJEK menawarkan manfaat besar baik untuk para pelanggan dan penyedia jasa (Junior, 2017).

Gojek Indonesia adalah suatu jasa transportasi yang ada di jakarta yang beroperasi sejak tahun 2011, Go-Jek merupakan pionir penyedia jasa layanan ojek profesional. Berusaha menawarkan faktor kecepatan, keamanan, dan kenyamanan bagi para konsumennya, Go-Jek tumbuh sebagai startup yang menjanjikan di ibukota. Untuk mengurangi permasalahan penyediaan uang tunai, Go-Jek menawarkan solusi e-wallet Go-Jek Credit. Bisa dibilang GoJek laksana Uber versi ojek yang cocok dimanfaatkan untuk mengantarkan barang, sarana transportasi, dan bahkan membantu kegiatan berbelanja di belantara Jakarta (Hisyam Lathif Ubaidillah, 2019). Saat ini Gojek memiliki layanan jasa yang beragam guna mendukung kebutuhan masyarakat yang semakin tinggi.
Gojek menambah jenis layanan lain yang bertujuan memudahkan aktivitas masyarakat sehari-hari seperti, Go-Food, Go-Shop, Go-Mart, Go-Clean, Go-Massage, Go-Glam, Go-Med.

Gojek memberikan kemudahan bertransaksi dengan memperkenalkan Go-Pay sebagai layanan pembayaran. Selain pembayaran konvensional yang dilakukan secara tunai, pembayaran secara nontunai atau cashless tentu akan memudahkan kita saat tidak membawa cukup uang untuk membayar jasa Gojek.

Go-Pay atau yang sebelumnya disebut sebagai Go-Wallet adalah dompet virtual untuk menyimpan Go Jek Credit Anda yang bisa digunakan untuk membayar transaksi-transaksi yang berkaitan dengan layanan di dalam aplikasi Gojekjasa Gojek.

Peraturan Otoritas Jasa Keuangan Nomor 76 Tahun 2016 menyatakan bahwa literasi keuangan merupakan pengetahuan (knowledge), keterampilan (skill), dan keyakinan (confidence), yang mempengaruhi sikap (attitude) dan perilaku (behavior) untuk meningkatkan kualitas pengambilan keputusan dan pengelolaan keuangan dalam rangka mencapai kesejahteraan.(Wiyono \& Kirana, 2020).

Literasi keuangan erat kaitannya dengan manajemen keuangan dimana semakin tinggi tingkat literasi keuangan seseorang maka makin baik pula manajemen keuangan seseorang tersebut. Manajemen keuangan pribadi 
Jurnal Akuntansi \& Perpajakan, Volume 2, No. 2, Januari 2021

merupakan salah satu aplikasi dari konsep manajemen keuangan pada level individu.

Menurut sumber dari Developing Indonesian Literacy Index dalam (Wahyu Rumbianingrum, 2015) dimensi dari literasi keuangan dibagi menjadi dua bagian yaitu basic financial literacy dan advanced financial literacy.

\section{Basic financial literacy terdiri dari}

1.1 Pengetahuan mengenai produk keuangan formal seperti persyaratan pembukaan rekening tabungan (identitas pembukaan rekening pembukaan bank, jumlah dana minimum pada saat membuka rekening bank, dan jumlah minimum saldo pada rekening bank, rekening tabungan yang di garansi oleh pemerintah).

\subsection{Numeracy regarding finance (perhitungan} keuangan) seperti bunga sederhana (simple interest), bunga majemuk (compounded interest), perhitungan bunga pinjaman.

1.3 Konsep dasar mengenai inflasi, diskon, time value of money, money illusion

2. Advanced financial literacy terdiri dari pasar saham, bunga rata-rata dan harga obligasi, pengembalian saham dan obligasi, risiko saham dan obligasi, arti pembelian obligasi, denda sebelum penjualan obligasi, investasi yang memberikan pengembalian tertinggi, investasi yang menghasilkan fluktuasi pengembalian yang tertinggi, dan asset diversification.

\section{METODE}

Metode yang digunakan pada penelitian ini adalah metode kuantitatif dengan tujuan penelitian yaitu jenis deskriptif. Teknis analisis data yang digunakan pada penelitian ini adalah menggunakan analisis deskriptif, Jenis penelitian ini dapat dikatakan sebagai penelitian kausalkomparatif yaitu tipe penelitian dengan karakteristik masalah berupa sebab akibat antara 2 variabel atau lebih. untuk melihat hubungan beberapa variabel yang belum pasti, menyebutkan desain kausal berguna untuk menganalisis bagaimana suatu variabel mempengaruhi variabel lain. (Sugiyono, 2016)

Untuk menentukan sampel yang akan digunakan dalam penelitian, terdapat berbagai teknik sampling yang digunakan. Dalam penelitian ini menggunakan teknik sampling Probability Sampling. Probability Sampling adalah teknik pengambilan sampel yang memberikan peluang yang sama bagi setiap unsur (anggota) populasi untuk dipilih menjadi sampel. (Sangadji. Sopiah, 2010)

\section{HASIL DAN PEMBAHASAN}

Alat analisis yang dipakai dalam penelitian ini Adalah software SPPS versi 23 dengan memakai analisis korelasi, hasil analisis dapat dilihat di bawah ini : 
Jurnal Akuntansi \& Perpajakan, Volume 2, No. 2, Januari 2021

Tabel. 3

Descriptive Statistics

\begin{tabular}{|l|r|r|r|}
\hline & \multicolumn{1}{|c|}{$\begin{array}{c}\text { Std. } \\
\text { Deviation }\end{array}$} & \multicolumn{1}{c|}{$\mathrm{N}$} \\
\hline Literasi Keuangan (Y) & 24,91 & 3,182 & 98 \\
Pengetahuan Penggunaan & 25,43 & 3,506 & 98 \\
\hline Fintech : Ovo / GoPay (X) & & & \\
\hline
\end{tabular}

Sumber : olah data spss, 2020

Analisis bagian Descriptive Statistics Rata-rata Literasi Keuangan (Y) dari 98 Data adalah 24,91 dengan standar deviasi 3,182. Rata-rata Pengetahuan Penggunaan Fintech : Ovo / GoPay (X) dari 98 Data adalah 25,43 dengan standar deviasi 3,506.

Tabel.4

One-Sample Kolmogorov-Smirnov Test

\begin{tabular}{|ll|r|}
\hline & & $\begin{array}{r}\text { Unstandardiz } \\
\text { ed Residual }\end{array}$ \\
\hline $\mathrm{N}$ & Mean & 98 \\
Normal & Std. Deviation & 1,93543107 \\
Parameters & a,b &, 127 \\
\hline Most Extreme & Absolute &, 077 \\
Differences & Positive &,- 127 \\
\hline Test Statistic & Negative &, 127 \\
Asymp. Sig. (2-tailed) &, $001^{\mathrm{c}}$ \\
\hline
\end{tabular}
a. Test distribution is Normal.
b. Calculated from data.
c. Lilliefors Significance Correction.

\section{Sumber : olah data spss, 2020}

Berdasarkan uji normalitas dengan Kolmogorov-Smirnov Test diperoleh nilai Asymp.sig. sebesar 0,001 lebih kecil dari 0,05 maka dapat disimpulkan data berdistribusi tidak normal. Maka Digunakan Teorema limit pusat ("central limit theorem") "Definisi :Teorema limit pusat ("central limit theorem") adalah sebuah teorema yang menyatakan bahwa kurva distribusi sampling (untuk ukuran sampel 30 atau lebih) akan berpusat pada nilai parameter populasidan akan memiliki semua sifat-sifat distribusi normal.”

\section{Gambar.1 \\ Histogram}

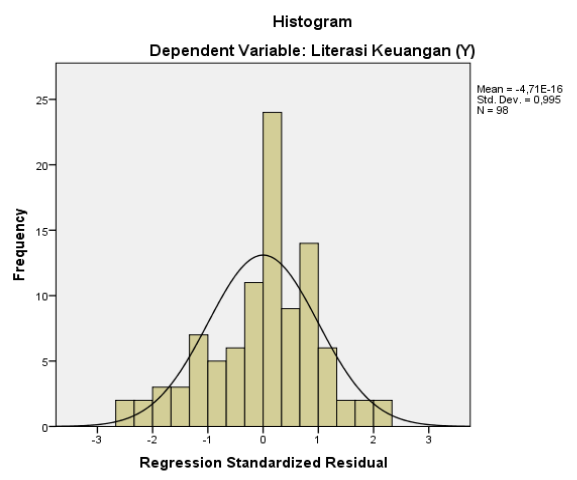

Sumber : olah data spss, 2020

Berdasarkan hasil output SPSS di atas kita dapat melihat grafik histogram memberikan pola distribusi yang menceng (skewness) ke kanan dan normal.

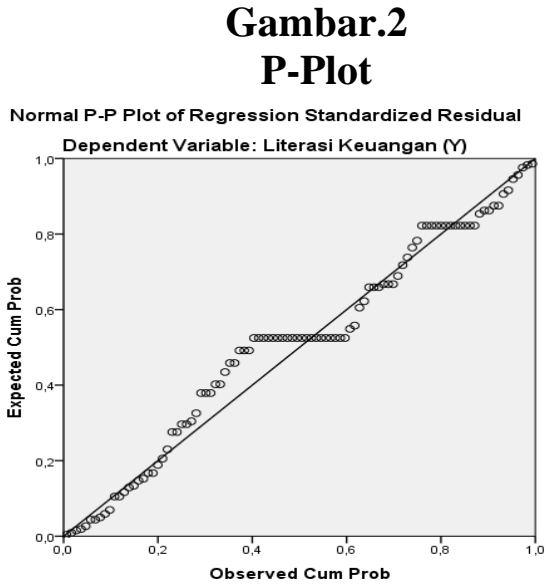

Sumber : olah data spss, 2020

Berdasarkan hasil output SPSS di atas kita dapat melihat grafik plot. Dimana gambar P-Plot terlihat titik-titik mengikuti dan mendekati garis 
Jurnal Akuntansi \& Perpajakan, Volume 2, No. 2, Januari 2021

diagonalnya sehingga dapat disimpulkan bahwa model regresi memenuhi asumsi normalitas (Sianipar, 2020).

Tabel. 5

Corelations

Correlations

\begin{tabular}{|c|c|c|c|}
\hline & & $\begin{array}{l} \\
\text { Literas } \\
\mathrm{i} \\
\text { Keuan } \\
\text { gan } \\
(\mathrm{Y})\end{array}$ & $\begin{array}{l}\text { Penget } \\
\text { ahuan } \\
\text { Penggu } \\
\text { naan } \\
\text { Fintech } \\
\text { : Ovo / } \\
\text { GoPay } \\
\text { (X) }\end{array}$ \\
\hline \multirow{2}{*}{$\begin{array}{l}\text { Pearson } \\
\text { Correlation }\end{array}$} & Literasi Keuangan (Y) & 1,000 &, 794 \\
\hline & $\begin{array}{l}\text { Pengetahuan Penggunaan } \\
\text { Fintech : Ovo / GoPay (X) }\end{array}$ & ,794 & 1,000 \\
\hline \multirow[t]{2}{*}{ Sig. (1-tailed) } & Literasi Keuangan $(\mathrm{Y})$ & & ,000 \\
\hline & $\begin{array}{l}\text { Pengetahuan Penggunaan } \\
\text { Fintech : Ovo / GoPay (X) }\end{array}$ &, 000 & \\
\hline \multirow[t]{2}{*}{$\mathrm{N}$} & Literasi Keuangan $(\mathrm{Y})$ & 98 & 98 \\
\hline & $\begin{array}{l}\text { Pengetahuan Penggunaan } \\
\text { Fintech : Ovo / GoPay (X) }\end{array}$ & 98 & 98 \\
\hline
\end{tabular}

Sumber : olah data spss, 2020

\section{Analisis bagian Correlations}

Besar hubungan antara Literasi Keuangan

(Y) dengan Pengetahuan Penggunaan Fintech :

Ovo / GoPay (X) dapat diketahui dengan melihat koefesien korelasi adalah 0,794. artinya nilai ini dapat menunjukkan hubungan yang sangat kuat antara Pengetahuan Penggunaan Fintech : Ovo / GoPay dengan Literasi Keuangan (Y), nilai koefesien korelasi semakin mendekati ke 1 maka semakin sempurna hubungan antara kedua variabel tersebut (arah hubungan ke positif).

Taraf kepercayan yang digunakan yaitu 0,05. diperoleh hasil tingkat signifikan koefesien korelasi sebesar 0,000. karena nilainya lebih kecil dari 0,05 maka hubungan Literasi Keuangan (Y) dengan Pengetahuan Penggunaan Fintech : Ovo / GoPay (X) berbeda secara nyata.

Tabel. 6 Model Summary Model Summary ${ }^{b}$

\begin{tabular}{|c|c|c|c|c|}
\hline $\begin{array}{l}\text { Mo } \\
\text { del }\end{array}$ & $\mathrm{R}$ & $\begin{array}{c}\mathrm{R} \\
\text { Squar } \\
\mathrm{e}\end{array}$ & $\begin{array}{c}\text { Adjusted R } \\
\text { Square }\end{array}$ & $\begin{array}{c}\text { Std. Error of the } \\
\text { Estimate }\end{array}$ \\
\hline 1 & ,794a & ,630 & ,626 & 1,945 \\
\hline
\end{tabular}

a. Predictors: (Constant), Pengetahuan Penggunaan Fintech : Ovo / GoPay (X)

b. Dependent Variable: Literasi Keuangan (Y)

Sumber : olah data spss, 2020

\section{Analisis bagian Model Summary}

Pada tabel model tersebut dapat diketahui bahwa nilai R sebesar 0,794 atau koefesien korelasi nilai $\mathrm{R}$ tersebut dapat dikuadratkan yaitu $0,794 \mathrm{x}$ $0,794=0,630 . R$ square (koefesien determinasi) dalam hal ini variasi dari variabel terikat (Literasi Keuangan (Y)) dapat dijelaskan oleh variabel bebas (Pengetahuan Penggunaan Fintech : Ovo / GoPay (X)) yaitu sebesar 63,0\%. sedangkan sisanya $37,0 \%$ dipengaruhi oleh faktor yang lain. Tingkat besarnya hubungan dari kedua varibabel tersebut dapat dilihat pada tabel berikut:

\begin{tabular}{|c|l|}
\hline Koefesien korelasi & \multicolumn{1}{|c|}{ Kekuatan hubungan } \\
\hline 0.00 & Tidak ada hubungan \\
\hline $0.01-0.09$ & Hubungan kurang berarti \\
\hline $0.10-0.29$ & Hubungan lemah \\
\hline $0.30-0.49$ & Hubungan moderat \\
\hline $0.50-0.69$ & Hubungan kuat \\
\hline $0.70-0.89$ & Hubungan sangal kual \\
\hline$>0.90$ & Hubungan mendekati sempuran \\
\hline
\end{tabular}


Jurnal Akuntansi \& Perpajakan, Volume 2, No. 2, Januari 2021

Dari tabel diatas dapat diketahui bahwa hubungannya sangat kuat antara Literasi Keuangan (Y) dengan Pengetahuan Penggunaan Fintech : Ovo / GoPay (X).

Standard Error of the Estimate sebesar 0,4243 dapat diartikan bahwa Literasi Keuangan (Y) yang dipakai dari variabel terikat sebesar 0,4243. sedangkan bila kita lihat pada tabel sebelumnya (tabel descriptive statistics) nilai standar deviasi Literasi Keuangan (Y) diperoleh sebesar 3,182, nilai ini menandakan standar error of the estimate lebih besar dari pada yang diperoleh dari model hanya 3,182.

Perkembangan Fintech diawali dengan hadirnya era industri 4.0, dimana kehadirannya mendisrupsi segala lini baik dalam bidang industri, teknologi, perbankan, hingga dunia pendidikan. Sebut saja Gojek,Grab, Kredivo, Traveloka, hingga OVO. Beberapa startup digital tersebut menawarkan beberapa kelebihannya untuk memudahkan masyarakat dalam hal transportasi, memesan makanan, hingga kemudahan dalam melakukan pinjaman uang.

Sehubungan dengan kebutuhan akan layanan keuangan yang menuntut teknologi kekinian yang dapat menghemat biaya serta waktu maka sudah selayaknya pemerintah setempat, institusi terkait bahkan perguruan tinggi harus memberikan dukungan bagi masyarakat sub urban untuk lebih meningkatkan pemahamannya mengenai Fintech. Keberhasilan masyarakat dalam memanfaatkan layanan keuangan tentunya akan mendorong peningkatan ekonomi masyarakat, ekonomi daerah bahkan ekonomi Indonesia. Untuk itu perlu dilakukan secara rutin edukasi dan pelatihan seperti ini untuk lebih meningkatkan pengetahuan dan pemahaman masyarakat akan layanan keuangan berbasis kekinian.

Perkembangan industri 4.0 khususnya fintech membawa angin segar sekaligus ancaman. Dengan adanya layanan fintech akan membuat layanan keuangan menjadi lebih cepat dan mudah.

\section{KESIMPULAN}

Kesimpulan dari penelitian ini adalah Pengaruh hubungan Pengetahuan penggunaan Fintech Ovo/Gopay berpengaruh sangat kuat dan positif terhadap Literasi Keuangan. Dan bisa dikatakan orang yang menggunakan fintech yaitu ovo/gopay akan memiliki pemahaman tentang literasi keauangan. Fintech merupakan salah satu cara untuk mendorong peningkatan ekonomi masyarakat melalui peningkatan transaksi keuangan. Untuk itu di era revolusi industri 4.0 dimana tehnologi meningkat dengan cepat sudah selayaknya masyarakat di pedesaan dapat pula menggunakan teknologi layanan keuangan ini sebagai tren yang harus diikuti.

\section{REFERENCES}

Hisyam Lathif Ubaidillah, . Nadia Asandimitra. (2019). PENGARUH DEMOGRAFI, DAN LITERASI KEUANGAN TERHADAP PERILAKU MENABUNG MASYARAKAT DI KABUPATEN SIDOARJO. Jurnal Ilmu Manajemen, 7(1), 242-249.

Junior, M. S. (2017). Fungsionalitas Konflik Gojek: Studi Fenomenologi Terhadap Konflik 
Jurnal Akuntansi \& Perpajakan, Volume 2, No. 2, Januari 2021

Pengemudi Gojek di Kota Kediri. Jurnal Analisa

Sosiologi, 6(1), 16-32.

MERTHA DEWI, I., \& Purbawangsa, I. B. A. (2018).

Pengaruh Literasi Keuangan, Pendapatan Serta

Masa Bekerja Terhadap Perilaku Keputusan

Investasi. E-Jurnal Ekonomi Dan Bisnis

Universitas Udayana, 7, 1867.

https://doi.org/10.24843/eeb.2018.v07.i07.p04

Muhamad Rizal, Erna Maulina, N. K. (2018).

FINTECH AS ONE OF THE FINANCING

SOLUTIONS FOR SMEs. Jurnal Pemikiran Dan

Penelitian Administrasi Bisnis Dan

Kewirausahaan, 74(4), 55-61.

Safitri, R., \& Andriansyah, M. (2020). Analisis

Penerimaan Teknologi Keuangan (FINTECH)

Terhadap Penggunaan Aplikasi Fintech OVO.

Jurnal Mitra Manajemen, 4(4), 538-549.

Sangadji. Sopiah. (2010). Metodologi Penelitian.

Yogyakarta: Pnerbit Andi.

Sianipar, A. Z. (2020). PERBEDAAN KEMAMPUAN

PEMECAHAN MASALAH DAN KOMUNIKASI

DAN PEMBELAJARAN LANGSUNG. 4(1), 14-

20. Retrieved from

http://journal.stmikjayakarta.ac.id/index.php/jisa

mar/article/download/167/136

Sugiyono. (2016). Metode Penelitian Kuantitatif,

Kualitatif dan $R \& D$. Bandung: PT Alfabet.

Wahyu Rumbianingrum, C. W. (2015). PENGARUH

LITERASI KEUANGAN TERHADAP

PENGELOLAAN KEUANGAN UMKM.

JURNAL MANAJEMEN DAN BISNIS

(ALMANA), 1(3), 155-165.

Wiyono, G., \& Kirana, K. C. (2020). Efek Impresi

Fintech Terhadap Perilaku Keuangan Usaha

Kecil Menegah (UKM). Jurnal Ilmiah

Manajemen Dan Bisnis, 21(1), 69-81.

https://doi.org/10.30596/jimb.v21i1.3889 